Paper kuliah Metode Penelitian I - IAKN Toraja

\title{
Hospitalitas Kristen Sebagai Upaya Mengatasi Sikap Individualisme di Tengah Pandemi Covid-19
}

\author{
Rensi Arnice Bangri' \\ Institut Agama Kristen Negeri Toraja \\ RensiArniceBangri'@gmail.com
}

\begin{abstract}
:
The Corona Virus Disease (Covid-19) pandemic is designated by WHO as a global pandemic because of its very high spread even in various countries including Indonesia. The Covid-19 pandemic has caused a lot of panic and public concern because of its very rapid spread. The Indonesian government made a social distancing / physical distancing policy. The policies given by the government caused various reaction. Many people see each other as strangers. Especially during a pandemic, many people take advantage of the situation for their own interests and benefits. The purpose of this paper is to show the importance of overcoming individualism in the midst of the Covid-19 pandemic based on the teory of Christian hospitality. Yhe method used is a qualitative method. The findings in this paperare: First, Christians must have love, care and not be individualistic. Second, individualism as a reaction to the emergence of the Covid-19 pandemic erodes a sence of hospitality.
\end{abstract}

Keywords: Individualism, hospitality, Christianity, Covid 19

\section{Abstrak:}

Pandemi Corona Virus Disease (Covid-19) ditetapkan oleh WHO sebagai pandemi global karena penyebarannya yang sangat tinggi bahkan sampai di berbagai negara termasuk di Indonesia. Pandemi Covid-19 banyak menimbulkan kepanikan dan kekhawatiran masyarakat karena penyebarannya yang sangat cepat. Pemerintah Indonesia membuat kebijakan social distancing/physical distancing. Kebijakan yang diberikan oleh pemerintah menimbulkan berbagai reaksi. Banyak orang yang cenderung bersikap individualisme. Sikap individualisme menimbulkan sikap tidak peduli terhadap orang lain dan lingkungannya karena lebih mementingkan diri sendiri dan kelompok sendiri dibandingkan mementingkan orang lain. Banyak orang melihat sesamanya sebagai orang asing. Terutama pada masa pandemi banyak orang yang justru memanfaatkan keadaan untuk kepentingan dan keuntungan diri sendiri. Tujuan tulisan ini yaitu memperlihatkan pentingnya mengatasi sikap individualisme di tengah pandemi covid-19 berdasarkan teori hospitalitas kristen. Metode yang digunakan yaitu metode kualitatif. Temuan dalam penulisan ini yaitu: pertama, orang Kristen harus memiliki kasih, 
kepedulian dan tidak bersikap individualisme. Kedua, individualisme sebagai reaksi terhadap munculnya pandemi covid-19 mengikis rasa hospitalitas.

Kata kunci: Individualisme, hospitalitas, Kristen, covid 19

\section{Pendahuluan}

Manusia sebagai makhluk sosial, dalam kehidupan sehari-hari pasti selalu melakukan interaksi dengan orang lain bahkan saling membutuhkan. Namun munculnya pandemi yang disebabkan oleh Virus Corona pada akhir tahun 2019 banyak menimbulkan kepanikan dan kekhawaitran karena penyebarannya yang sangat cepat bahkan mematikan. Covid-19 menyerang sistem pernafasan pada manusia dan menyebar dengan sangat cepat di berbagai negara sehingga WHO menetapkan Covid-19 sebagai pandemi global. ${ }^{1} \mathrm{Di}$ Indonesia Pemerintah kemudian mengeluarkan kebijakan social distancing/physical distancing agar tidak terjadi kerumunan yang dapat mempercepat penularan dan perkembangan Covid 19.

Kebijakan atau peraturan yang diberikan oleh pemerintah bertujuan agar masyarakat tidak berkerumun dan selalu menjaga diri sendiri. Kebijakan tersebut diterima oleh masyarakat namun menimbulkan berbagai reaksi. ${ }^{2}$ Reaksi yang ditimbulkan dari kebijakan tersebut berdampak pada kehidupan sosial masyarakat termasuk di dalamnya adalah rasa curiga terhadap orang lain dan kecenderungan untuk bersikap individualisme. Banyak orang yang egois dan tidak peduli terhadap orang lain dan lingkungannya karena lebih mementingkan kebutuhan diri sendiri.

Tindakan atau sikap individualisme yang tidak menujukkan kepedulian terhadap orang lain merupakan sikap yang tidak boleh dilakukan oleh orang Kristen. Orang Kristen seharusnya berperan untuk tetap peduli dan menunjukkan kasih terhadap orang lain dan lingkungan sekitarnya dengan tulus tanpa mengharapkan imbalan. Kasih dan kepedulian terhadap orang lain merupakan inti ajaran dan perintah Allah bagi orang Kristen. ${ }^{3}$

\footnotetext{
${ }^{1}$ Muhamad Arif Saefuding. "Budaya dan Pandemi Covid-19: Kolektifis atau Individualis?" 2020: 1-2.

${ }^{2}$ Daniel Fajar Panuntun and Eunike Paramita, "Hospitalitas Kristen Dan Tantangannya Di Tengah Pandemi Covid-19," Harmoni 19, no. 1 (2020): 71-72.

${ }^{3}$ E. B Surbakti. "Benarkah Injil Kabar Baik?: bagaiamana menyatakannya dalam perspektif lokas?” Jakarta: BPK Gunung Mulia, 2008.
} 
Rumusan masalah pada tulisan ini yaitu: apa itu Hospitalitas Kristen dan sikap individualisme? Serta bagaimana mengatasi sikap individualisme di tengah pandemi covid 19 berdasarkan teori hospitalitas kristen?. Tujuan tulisan ini yaitu menemukan cara atau sikap yang baik hospitalitas Kristen dalam mengatasi sikap individualisme di tengah pandem covid 19. Manfaatnya yaitu mengembangkan analisi mengenai cara mengatasi sikap individualisme di tengah pandemi covid 19 berdasarkan teori hospitalitas kristen.

\section{Pembahasan}

Tulisan ini akan membahas mengenai bagaiman cara atau sikap yang baik hospitalitas Kristen dalam mengatasi sikap individualisme di tengah pandemi Covid-19. Dimana pada masa pandemi Covid-19 kebijakan social distancing/physical distancing banyak menimbulkan reaksi dari masyarakat. Masyarakat cenderung memikirkan diri sendiri, menjauhi orang lain, bahkan mencurigai orang lain secara berlebihan. Sikap individualisme ini tentu bertentangan dengan rasa hospitalitas yang seharusnya dimiliki oleh setiap individu terutama bagi orang Kristen.

\section{A. Hospitalitas Kristen dan Individualisme}

Pada masa pandemi covid-19, kegiatan berkomunikasi antar individu harus dilakukan dengan tetap mematuhi kebijakan social distancing/physical distancing. Istilah social distancing/physical distancing sering dibicarakan pada masa pandemi Covid-19 sebagi upaya untuk mengurangi resiko terinfeksi atau tertular Covid-19. Pandemi Covid-19 menimbulkan berbagai reaksi yang berdampak pada kehidupan sosial masyarakat. Masayarakat mulai menemukan kebiasaan-kebiasaan baru yang memunculkan kebiasaan baru. Masyarakat harus bersosialisasi dengan orang lain sambil tetap mematuhi protokol kesehatan. Bahkan banyak orang yang mulai hidup dengan sikap indiviualime, tidak peduli dengan sesama dan lingkungannya karena lebih mementingkan kebutuhan diri sendiri.

Dalam Kamus Besar Bahasa Indonesia (KBBI), Individualisme merupakan paham yang mementingkan hak perseorangan di samping kepentingan masyarakat atau negara. Individualisme lebih kepada sikap yang mementingkan kebebasan pribadi atau lebih mementingkan diri sendiri dibandingkan mementingkan orang lain. sikap individualisme sendiri menyebabkan orang tidak mau terlibat secara sosial. 
Sikap individualime tentu tidak mencerminkan hospitalitas. Secara etimologi, Hospitalitas berasal dari bahasa Yunani "Philoxenia". "Philoxenia terdiri dari dua kata yaitu "philos" yang berarti kasih, dan "Xenos" yang berarti orang asing, yang lain. Jadi, secara harfiah Hospitalitas berarti kasih kapada orang lain atau kasih kepada orang asing. 4 Dengan demikian, Hospitalitas tidak hanya berbicara mengenai kasih terhadap sesama tetapi juga mengenai kasih terhadap orang asing. Mungkin menjadi suatu hal yang mudah untu mengasihi sesama kita. tetapi sebagai orang Kristen, selain mengasihi sesama kita juga diajak untuk mengasihi semua orang. Hospitalitas merupakan sebuah keramatamahan seseorang terhadap orang lain atau kelompok lain. ${ }^{5}$

\section{B. Hospitalitas Kristen Sebagai Upaya Mengatasi Sikap Individuaisme di Tengah Pademi Covid-19}

Pandemi Covid-19 yang menimbulkan sikap individualisme menyebabkan banyak orang kehilangan rasa hositalitas termasuk orang Kristen. Seperti yang kita ketahui bahwa inti pengajaran iman Kristen adalah kasih, maka sikap individualisme merupakan sikap yang tidak memancarkan kasih kepada sesama. Menyatakan kasih kepada sesama merupakan tanggung jawab iman orang kristen. Kasih menjadi sesuatu yang penting seperti yang yang dikatakan dalam 1 Kor. 13:1 "sekalipun aku dapat berkata-kata dengan semuah bahasa manusia dan bahasa malaikat, tetapi jika aku tidak mempunyai kasih, aku sama dengan gong yang berkumandang dan canang yang gemerincing". ${ }^{6}$ Begitu pentingnya kasih sehingga segala sesuatu yang dimiliki tidak berguna jika kasih tidak ada dalam diri kita sebagai orang Kristen. Lebih lanjut dalam 1 Kor. 13:13 menyatakan bahwa antara iman, pengaharapan dan kasih yang paling besar adalah kasih.

Dengan demikian, sikap individualisme meruakan sikap yang tidak menampakkan kasih karena lebih mementingkan diri sendiri. Tanpa kasih seseorang tidak mungkin rela berkorban bagi sesamanya. Orang Kristen hendaknya mengekspresikan kasih sebagai wujud hospitalitas Kristen dalam mengatasi sikap

\footnotetext{
4 Yohanes K. Susanta, "Hospitalitas Sebagai Upaya Mencegah Kekerasan Dalam Memelihara Kerukunan Dalam Relasi Islam - Kristen Di Indonesia," Societas Dei: Jurnal Agama dan Masyarakat 2, no. 1 (October 2017): 72 73

5 Panuntun, Daniel Fajar. "Nilai Hospitalitas Dalam Budaya Longko'Torayan." In Teologi Kontekstual Dan Kearifan Lokal Toraja, 19, 2020. 28

${ }^{6}$ E. B Surbakti, "Benarkah Injil Kabar Baik?: bagaiamana menyatakannya dalam perspektif lokas?." Jakarta: BPK Gunung Mulia, 2008. HIm. 64-66
} 
individualisme di tengah pandemi Covid-19. Tindakan atau sikap individualisme yang tidak menujukkan kepedulian terhadap orang lain merupakan sikap yang tidak boleh dilakukan oleh orang Kristen. Orang Kristen seharusnya berperan untuk tetap peduli dan menunjukkan kasih terhadap orang lain dan lingkungan sekitarnya dengan tulus tanpa mengharapkan imbalan.

Hospitaitas memiliki peran penting dalam proses penyataan kasih Allah bagi dunia. Hospitalitas Kristen berhubungan dengan tindakan kita sebagai orang Kristen dalam mengasihi orang lain atau orang asing. Karena itu, pada masa pandemi covid-19 saat ini, yang harus dilakukan oleh orang Kristen untuk mengatasi sikap individualisme yaitu memahami tanggung jawab sebagai orang kristen untuk mengasihi sesama bahkan orang asing, dan tidak hanya mementingkan diri sendiri. Dengan kata lain bahwa orang Kristen harus selalu mengasihi orang lain terutama dalam konteks pandemi Covid-19 dengan tetap mematuhi kebijakan yang diberikan oleh pemerintah. 


\section{Kesimpulan}

Sika Individualisme merupakan kepada sikap yang mementingkan kebebasan pribadi atau lebih mementingkan diri sendiri dibandingkan mementingkan orang lain. Sikap ini harus diatasi dengan tetap mewujudkan kasih kepada sesama dan orang asing sebagai tanggungjawab orang Ksisten. Pada masa pandemi covid-19 saat ini, yang harus dilakukan oleh orang Kristen untuk mengatasi sikap individualisme yaitu memahami tanggung jawab sebagai orang kristen untuk mengasihi sesama bahkan orang asing, dan tidak hanya mementingkan diri sendiri. Dengan kata lain bahwa orang Kristen harus selalu mengasihi orang lain terutama dalam konteks pandemi Covid-19 dengan tetap mematuhi kebijakan yang diberikan oleh pemerintah. 


\section{DAFTAR PUSTAKA}

Panuntun, Daniel Fajar, and Eunike Paramita. "Hospitalitas Kristen dan Tantangannya di Tengah Pandemi Covid-19." Harmoni 19, No.1, 2020: 67-84.

Saefuding, Muhamad Arif. "Budaya dan Pandemi Covid-19: Kolektifis atau Individualis?" n.d.

Surbakti, E. B. Benarkah Injil Kabar Baik?: bagaiamana menyatakannya dalam perspektif lokas? jakarta: BPK Gunung Mulia, 2008.

Susanta, Yohanes Krismantio. "Hosptalitas Sebagai Upaya Mencegah dan Memelihara Kerukunan dalam Relasi Islam Kristen Di Indonesia." Jurnal Agama dan Masyarakat, october 2017: 303.

Panuntun, Daniel Fajar. “Nilai Hospitalitas Dalam Budaya Longko'Torayan.” In Teologi Kontekstual Dan Kearifan Lokal Toraja, 19, 2020. 